\title{
Effect of pH on the Turbidity Removal of Wastewater
}

\author{
Shahad Salim Mohammed \\ Chemical and Petrochemical Engineering Department, University of Anbar, Ramadi, Iraq \\ Email: shahadsalim44@yahoo.com
}

Received 9 December 2015; accepted 25 December 2015; published 28 December 2015

Copyright (C) 2015 by author and OALib.

This work is licensed under the Creative Commons Attribution International License (CC BY). http://creativecommons.org/licenses/by/4.0/

(c) (i) Open Access

\section{Abstract}

The aim of this work was to show the effect of change in $\mathrm{pH}$ on removing turbidity, the concentration of turbidity $(100,300)$ NTU, where the turbidity was removed by using activated carbon column (height $11 \mathrm{~cm}$ and internal diameter $8 \mathrm{~cm}$ ) and contained a cotton filter in the bottom of it, $\mathrm{pH}$ range $(5,7,10)$, by using $\mathrm{pH}$ adjustment $(\mathrm{HCL}, \mathrm{NaOH})$, alum and ferric chloride was used as additive. The results showed that the activated carbon had excellent results for removal turbidity, and the removal efficiency was enhanced with increasing $\mathrm{pH}$ the best results at $\mathrm{pH}(7,10)$ and also when adding alum and ferric chloride, but the effect of ferric chloride was more than alum in removing turbidity.

\section{Keywords}

pH, Turbidity, Wastewater Treatment, Tube, Additive

\section{Subject Areas: Environmental Sciences}

\section{Introduction}

Turbidity is the amount of cloudiness in the water. This can vary from a river full of mud and silt where it would be impossible to see through the water (high turbidity), to a spring water which appears to be completely clear (low turbidity).

Turbidity can be caused by:

•silt, sand and mud.

-bacteria and other germs.

-chemical precipitates.

It is very important to measure the turbidity of domestic water supplies, as these supplies often undergo some type of water treatment which can be affected by turbidity. For example, during the rainy season when mud and silt are washed into rivers and streams, high turbidity can quickly block filters and stop them from working ef- 
fectively. High turbidity will also fill tanks and pipes with mud and silt, and can damage valves and taps.

Where chlorination of water is practiced, even quite low turbidity will prevent the chlorine killing the germs in the water efficiently. Some treatment systems, such as sediments, coagulators and gravel pre filters are designed to remove turbidity. It is important for operators of both large and small treatment systems to know how well these systems are working. Measuring the turbidity of the water before and after each part of the system can tell the operator where maintenance or cleaning is needed [1].

Clarity of water is important in producing products destined for human consumption and in many manufacturing operations. Beverage producers, food processors, and potable water treatment plants drawing from a surface water source commonly rely on fluid-particle separation processes such as sedimentation and filtration to increase clarity and insure an acceptable product. The clarity of a natural body of water is an important determinant of its condition and productivity. Turbidity in water is caused by suspended and colloidal matter such as clay, silt, finely divided organic and inorganic matter, and plankton and other microscopic organisms. Turbidity is an expression of the optical property that causes light to be scattered and absorbed rather than transmitted with no change in direction or flux level through the sample. Correlation of turbidity with the weight or particle number concentration of suspended matter is difficult because the size, shape, and refractive index of the particles affect the light-scattering properties of the suspension. When present in significant concentrations, particles consisting of light-absorbing materials such as activated carbon cause a negative interference. In low concentrations, these particles tend to have a positive influence because they contribute to turbidity. The presence of dissolved, color-causing substances that absorb light may cause a negative interference. Some commercial instruments may have the capability of either correcting for a slight color interference or optically blanking out the color effect [2].

The objective of this study was to develop a treatment system that can effectively reduce the concentration of colloidal particles in raw water that can greatly reduce the cost of treatment and improve the subsequent steps of treatment. Aluminum sulphate (alum) and ferric chloride as a coagulant and anionic polymer as coagulant aid were used in the process that changed the scale of particles from Nano scale to micro scale and larger by a physico-chemical process. The influence of $\mathrm{PH}$, temperature, coagulant and coagulant aid dosages on the coagulation process was studied and conditions were optimized corresponding to the best removal of organic matters, viruses, colloids, bacteria, color and decrease in turbidity. $85 \%$ - 98\% reduction of turbidity from raw water can be achieved by using the optimum coagulant dosage ( $8 \mathrm{ppm}$, ferric chloride/10 ppm, alum) in the optimum $\mathrm{PH}$ range (9.2, ferric chloride/8.5, alum) in the optimum temperature $\left(20^{\circ} \mathrm{C}\right.$, ferric chloride/ $24^{\circ} \mathrm{C}$, alum). Ferric chloride produced better results than alum. Higher dosages did not significantly increase pollutant removal and were not economical. The results provide useful information for raw water treatment [3].

Effective removal of turbidity and soluble dissolved organic matter (DOM) from the Agbo reservoir water was investigated, since DOM can lead to the formation of potential carcinogens compounds during water disinfection. An enhanced coagulation with alum was then conducted by standard jar test to optimize coagulation $\mathrm{pH}$ and alum dose. Optimum removal of turbidity (98\%) and dissolved organic carbon (DOC) (70\%) was achieved for $100 \mathrm{mg}$ alum L-1 at $\mathrm{pH}$ 5. Alum dose and $\mathrm{pH}$ control of coagulation were found to be important factors governing DOM removal. It was also showed that humic substances are rather more removed by alum than the other DOC compounds [4].

\section{Materials}

- Tap water.

- Clay.

- Activated carbon.

- Cotton filter.

- $\mathrm{pH}$ adjustment was done by using ( $\mathrm{NaOH}$ molecular weight is $40 \mathrm{gm} / \mathrm{mole}$ and purity of $100 \% \mathrm{HCl}$ molecular weight is $98.08 \mathrm{gm} / \mathrm{mole}$ and purity of $100 \%)$.

- Aluminum sulfate (Alum) Commercial alum was used in the experiments, it is a white dry powder, has a formula of $\left(\mathrm{Al}_{2}\left(\mathrm{SO}_{4}\right)_{3} \cdot 18 \mathrm{H}_{2} \mathrm{O}\right)$ and molecular weight of $(594.4 \mathrm{gm} / \mathrm{mole})$.

- Ferric chloride $\left(\mathrm{FeCl}_{3}\right)$ it molecular weight 162.2 (gm/mole) Anhydrous: green-black powder Heptahydrate: Yellow-brown lump Liquid: dark-brown solution. 


\subsection{Experiment Procedure}

- The experimental procedure was done by preparing the sample of turbid water in $(100,300) \mathrm{NTU}, \mathrm{pH}(7)$, was poured gently on the top of the tank (height $35 \mathrm{~cm}$, diameter $25 \mathrm{~cm}$ ) contain activated carbon column inside it (11 cm for the height and $8 \mathrm{~cm}$ in diameter) consists of an activated carbon layer and contain a cotton filter in the bottom about $1.5 \mathrm{~cm}$ in thickness as shown in Figure 1 and Figure 2 show the samples before and after the treatment without any additive and at $\mathrm{pH}$ (7).

- The experimental procedure above was repeated in different value of $\mathrm{pH}(5,7,10)$.

- Repeat the procedure on concentration 300 NTU.

- In order to increase the removal efficiency of turbidity alum and ferric chloride was added at the best $\mathrm{pH}$ of the solution.

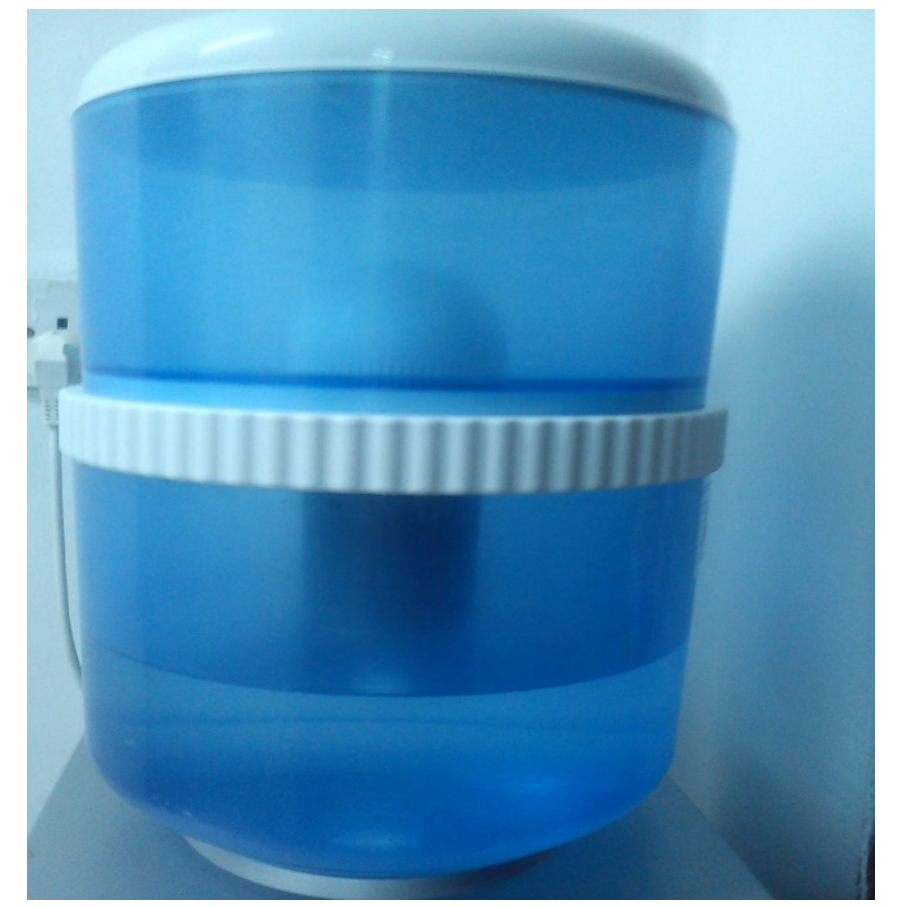

Figure 1. Activated carbon tank for treatment turbid water.

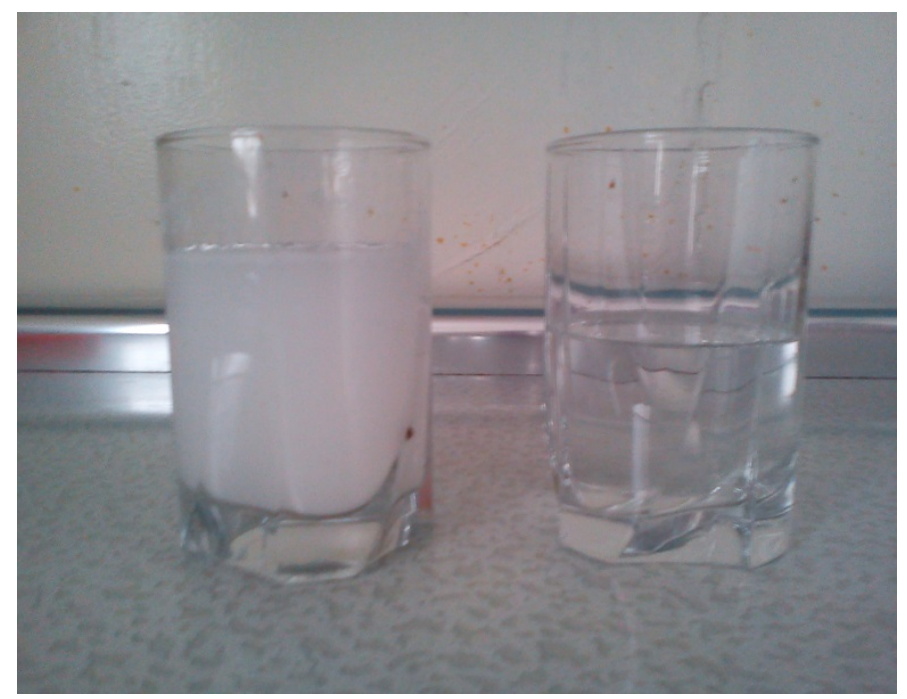

Figure 2. The samples before and after the treatment. 


\subsection{Turbidity Measurement}

Turbidity is a measure of the cloudiness of water. The higher the turbidity, the harder it is to see through the water. Turbidity measurements are reported in nephelometric turbidity units (NTU) or Jackson turbidity units (JTU). Different units are used depending on which method is chosen to measure turbidity. The two units are roughly equivalent and can be used interchangeably for field purposes. The NTU will be used for the remainder of this paper With the naked eye, an average person can begin to see turbidity levels starting at around 5 NTU and greater. Lakes that are considered relatively clear in the United States can have a turbidity up to 25 NTU [5]. If water appears muddy, its turbidity has reached at least 100 NTU. At 2000 NTU, water is completely opaque [6]. Figure 3 shows turbidities of $<10$ NTU, 200 NTU and 1500 NTU.

Turbidity consists of a number of substances. Mud, silt, sand, small pieces of dead plants, bacteria, aquatic organisms, algae, and chemical precipitates all contribute to turbidity.1 Erosion, waste discharge, and urban runoff can add suspended solids to a body of water. Agricultural runoff, in addition to directly increasing suspended solids, can also contribute to the growth of algae. After a storm or flooding, turbidity in surface water generally increases rapidly due to the increase in runoff.

Turbidity is a key indicator used in assessing the suitability of water for human consumption.

The material suspended in turbid water can contain a large number of pathogens. High turbidity can also have a variety of negative effects on various methods of water use and treatment. Pipes carrying turbid water can become clogged with sediment. Turbidity can also stimulate the growth of bacteria, Along with E. coli, $\mathrm{pH}$, and chlorine residual, turbidity is one of the key parameters of microbial water quality [8]. It is also used to measure the effectiveness of water filtration.

Several methods are available to test turbidity in water. These are summarized in Table 1.

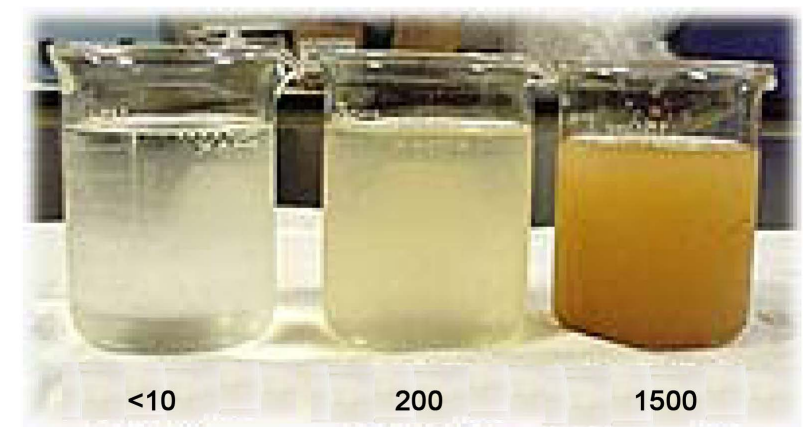

Figure 3. Sample turbidities [7].

Table 1. Turbidity measurement methods [9].

\begin{tabular}{|c|c|c|}
\hline Method & advantage & disadvantage \\
\hline $\begin{array}{l}\text { Jackson Candle Turbid meter } \\
\text {-Water poured into tube. } \\
\text {-Reading taken when candle burning under tube can } \\
\text { no longer be seen. }\end{array}$ & (Historical method.) & $\begin{array}{l}\text { No longer a standard method. } \\
\text { Can’t measure }<25 \text { JTU ( } 25 \text { NTU). }\end{array}$ \\
\hline $\begin{array}{l}\text { Turbid meter (Nephelometer) } \\
\text {-Beam of light passed through water sample. } \\
\text {-Amount of light scattered at a } 90^{\circ} \text { angle measured. }\end{array}$ & $\begin{array}{l}\text { Extremely accurate. } \\
\text { Some are portable. } \\
\text { Can measure very low turbidity. }\end{array}$ & $\begin{array}{l}\text { Expensive. } \\
\text { Easily damaged. } \\
\text { Requires power source. } \\
\text { Requires calibration. }\end{array}$ \\
\hline $\begin{array}{l}\text { Secchi Disk } \\
\text {-Black and white disk lowered into water. } \\
\text {-Maximum distance at which disk can be seen recorded. }\end{array}$ & $\begin{array}{l}\text { Low cost. } \\
\text { Portable. } \\
\text { No consumables. } \\
\text { Easy to learn }\end{array}$ & $\begin{array}{l}\text { Less accurate. } \\
\text { Can’t be used in shallow water } \\
\text { or swift currents. } \\
\text { Not applicable to small sample size. }\end{array}$ \\
\hline $\begin{array}{l}\text { Turbidity Tube (Transparency Tube) } \\
\text {-Combination of Jackson candle and Secchi disk methods. }\end{array}$ & $\begin{array}{l}\text { Low cost. } \\
\text { Portable. } \\
\text { No consumables. } \\
\text { Easy to learn. } \\
\text { Suitable for all water sources. }\end{array}$ & $\begin{array}{l}\text { Less accurate. } \\
\text { Can't measure }<5 \text { NTU. }\end{array}$ \\
\hline
\end{tabular}


So, from the table above the turbidity tube was used as a measurement method of this research, where a turbidity tube is made up of four key components:

1) A Clear Tube.

2) A Tube Cap.

3) A Viewing Disc.

4) A Measuring Device.

You will need to be able to see the viewing disk from the top of your clear tube. The placement of the disk will depend on your tube cap. The disk can be dropped to the bottom of your tube if it is not made of a floating material. A dropped disk will need to be marked on both sides. You can also attach the disk to your tube cap with adhesive so that it will be visible when the cap is inserted. Another possibility is to mark the tube cap with a checkered pattern so that it can be treated as a viewing disk.

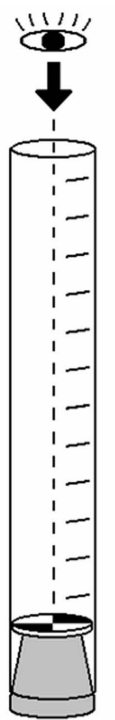

4

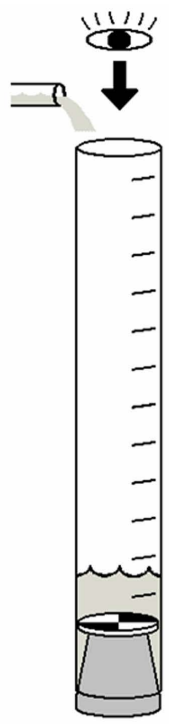

5

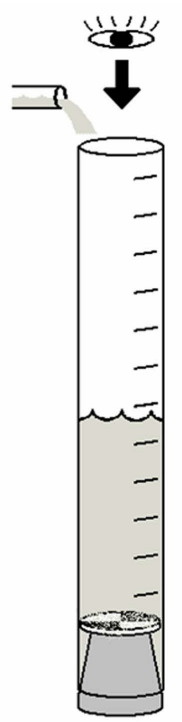

6

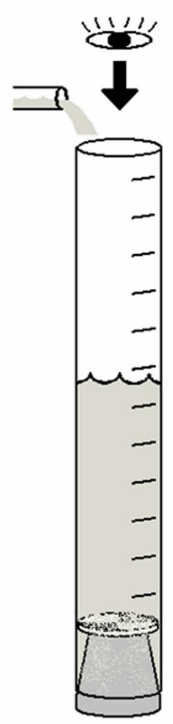

7

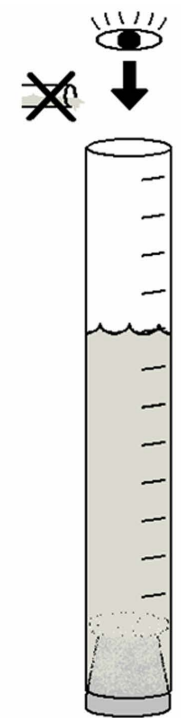

7-STOP!

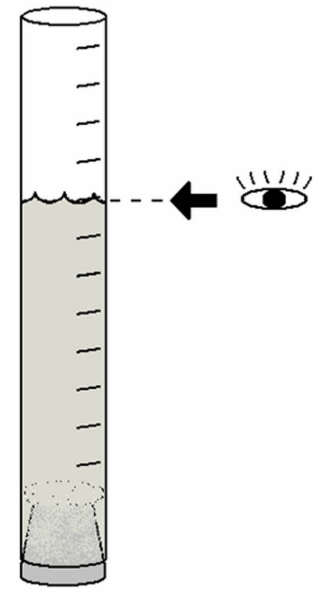

8

\section{Results and Discussion}

From the experimental procedure above can be resulted by the first relation showed the effect of $\mathrm{pH}$ on the removal of turbidity on both concentration $(100,300) \mathrm{NTU}$, three value of $\mathrm{pH}$ was used $(5,7,10)$ to see it effect on the removal efficiency, we can see from Figure 4 and Figure 5 the best removal efficiency at $\mathrm{pH}(10)$, therefore we can concluded the turbidity removal was increase with increasing $\mathrm{pH}$, that because in higher $\mathrm{pH}$ there's reduction of turbidity because in higher $\mathrm{pH}$ there's a tendency toward sedimentation and fundamentally alkaline basic is a suitable place for sedimentation that agreement with [3].

In Figure 4: The concentration of turbidity is $(100) \mathrm{NTU}$, but different $\mathrm{pH}$ where $\mathrm{pH}$ used in $(5,7,10)$ to see the effect of removal in clearly, so after the sample treated in a column and measured the amount of turbidity after treatment its notice that the maximum removal at $\mathrm{pH}$ (10), In Figure 5 the concentration of turbidity is (300) and also in different $\mathrm{pH}$, after the treatment found the maximum removal is $\mathrm{pH}$ (10) but, the removal efficiency is higher than the concentration (100).

In Figure 6 and Figure 7 showed the effect of adding alum on removing turbidity on both concentration (100, 300) NTU the results showed higher removal of turbidity when adding the same amounts of alum and enhanced the removal efficiency, depended on the initial turbid water concentration, where the higher initial concentration having more efficient removal. In natural water, most particles (including microorganisms) have a negative electric charge and, rather than clump together to form larger particles, the particles repel each other.

To get the particles in solution to form larger clumps, this negative charge must be neutralized. This can be done by adding positive ions, such as aluminum or ferric ions, which react with the negative particles and form clusters of particles called microflocs. The microfloc then grows and will either settle out or can be filtered out of the water by a treatment system such as sand filtration. 


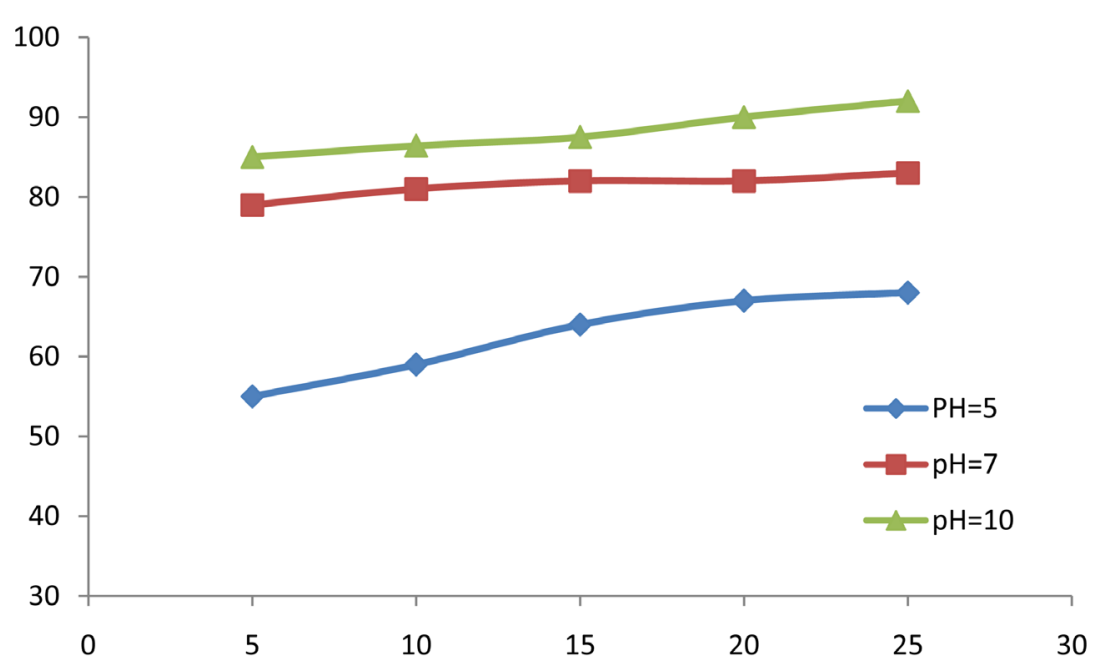

Figure 4. EFFECT of pH on turbidity removal at 100 NTU.

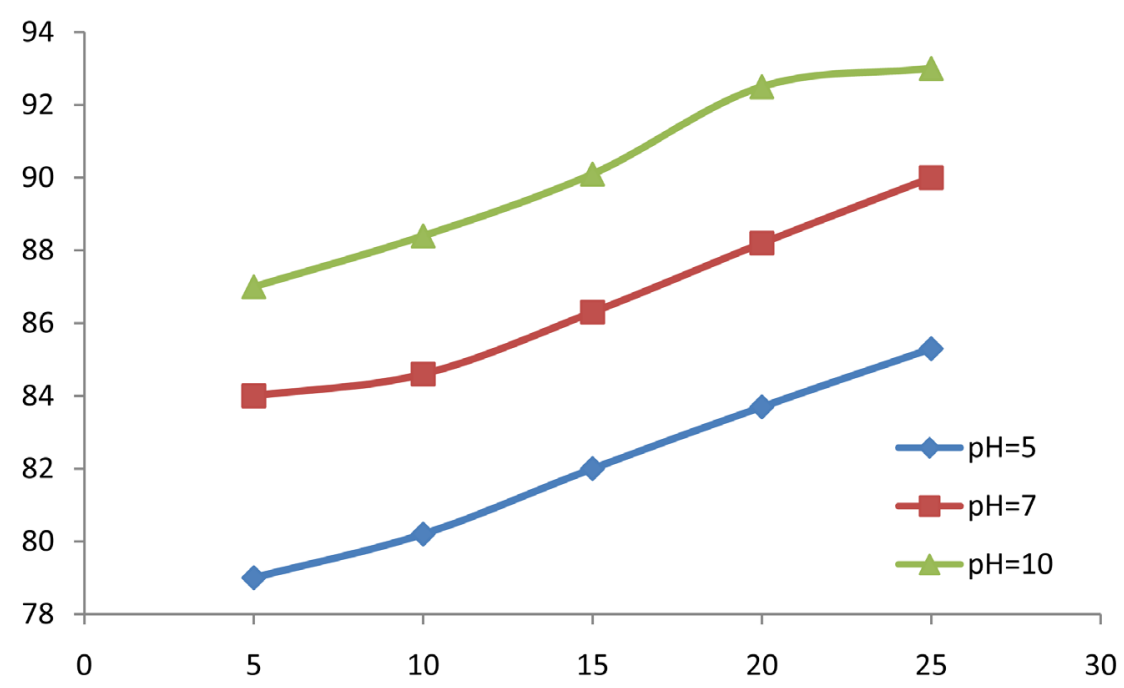

Figure 5. EFFECT of pH on turbidity removal at 300 NTU.

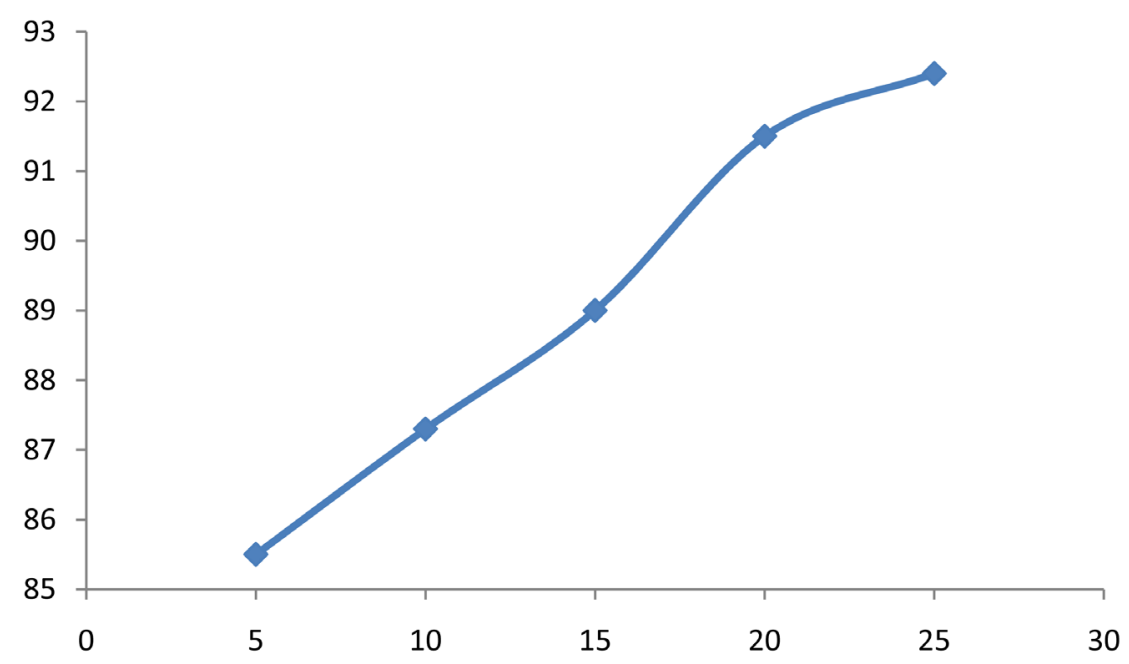

Figure 6. Effect of adding (9) ppm of alum in (100) NTU turbid water. 


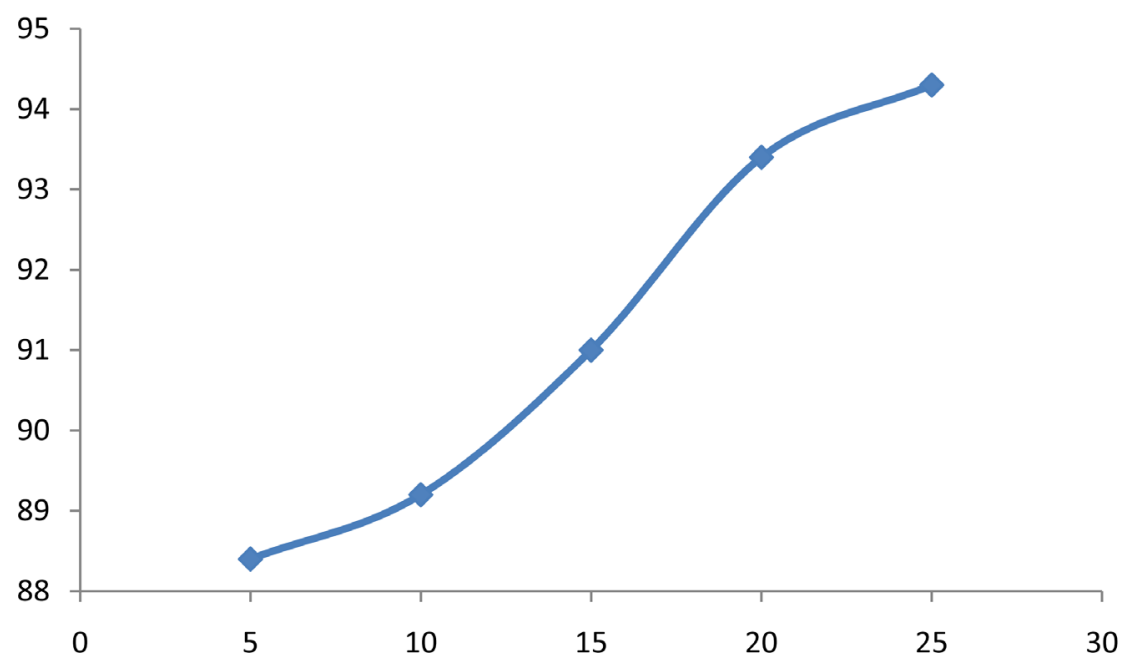

Figure 7. Effect of adding (18) ppm of alum in (300) NTU turbid water.

Aluminum sulphate is the most common chemical used for the coagulation of particles. During coagulation, several other undesirable impurities in water are also removed, including naturally occurring organic matter, which reacts with chlorine to form disinfection by-products that may be carcinogenic. Coagulation is an essential step in effective water treatment and, when carried out properly, the residual amount of aluminum in the finished drinking water is small. Other coagulants, such as ferric chloride, are more hazardous to work with. Some coagulation chemicals are organic polymers blended with aluminum- or iron-based products-these are more costly and are generally used only under special circumstances [11].

In Figure 8 and Figure 9 showed the removal efficiency enhancement and it's increasing when ferric chloride was added in the same concentration for both $(100,300)$ NTU.

That's because when adding additive cause to increase the $\mathrm{pH}$ value so increase the removal of turbidity, the effect of increasing the $\mathrm{pH}$ value on the reduction of turbidity for ferric chloride is stronger than alum and ferric chloride dosage is less than the alum dosage in the same $\mathrm{pH}$ value, Basic equations occurring during the coagulation process for ferrous sulfate is given in the following equation:

$$
\mathrm{FeSO}_{4}+2 \mathrm{HCO}_{3} \rightleftharpoons \mathrm{Fe}(\mathrm{OH})_{2}+\mathrm{SO}_{4}^{2-}+2 \mathrm{CO}_{2}
$$

Hydrolysis of $\mathrm{FeSO}_{4}$ during coagulation results in the formation of corresponding gel like hydroxides and some positively charged mononuclear and poly-nuclear species. These positively charged compounds combine with negatively charged colloidal particles present in the wastewater by charge neutralization mechanism and at the time of settling under gravity these hydroxides and complexed hydroxides sweep away remaining uncharged/charged colloidal particles of the wastewater with them and precipitates out. Varying ferrous sulfate concentrations were applied for the treatment of wastewater [12].

And above us all, also we must not forget the effect of active carbon in removal efficiency and cotton filter for good treatment and results, where Activated carbon (AC) is similar to ion exchange resin in density and porosity. It adsorbs many dissolved organics and eliminates chlorine or other halogens in water. It does not remove salts. AC filters are one of the only low-cost methods available to remove low-molecular weight ( $<100 \mathrm{MW})$ organics and chlorine. AC filters may become a breeding site for bacteria and pyrogenic materials. The carbon must be sanitized or changed periodically to avoid bacterial growth, and when all adsorption sites are used it must be reactivated by a controlled heat process. This is not easily reactivated in the field. The suspended solids accumulated in the bed from most water sources require frequent backwashing of the filter unless installed after reverse osmosis or ultrafiltration [10].

\section{Conclusions}

The aim of this work was to show the effect of change in $\mathrm{pH}$ on removing turbidity, the concentration of turbidity $(100,300)$ NTU, where the turbidity was removed by using activated carbon column (height $11 \mathrm{~cm}$ and in- 


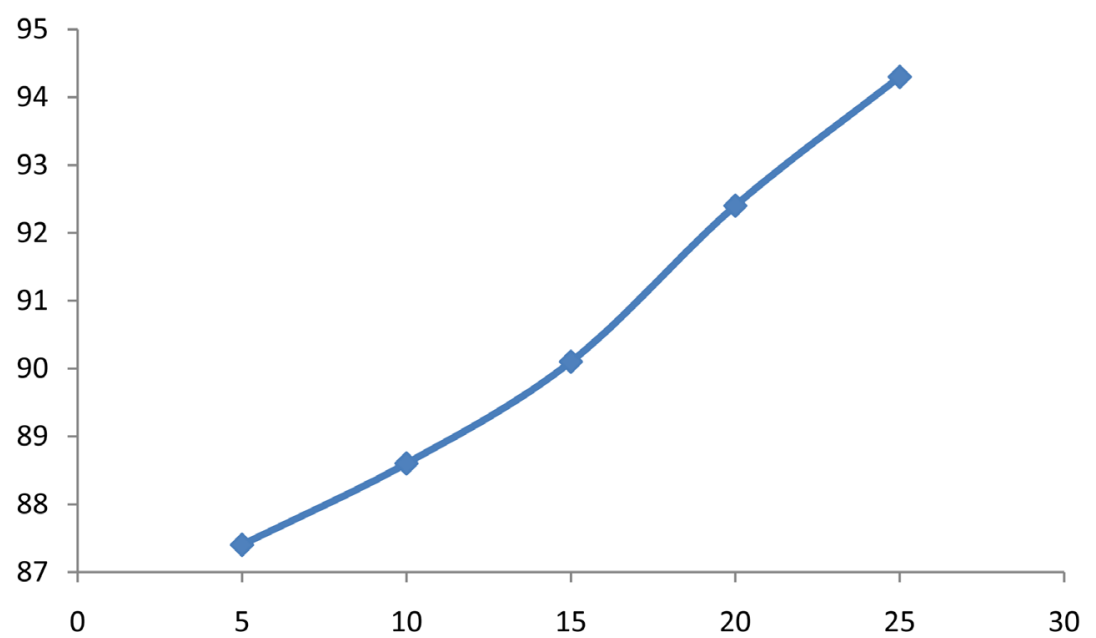

Figure 8. Effect of adding (9) ppm of $\mathrm{FeCl}_{3}$ in (100) NTU turbid water.

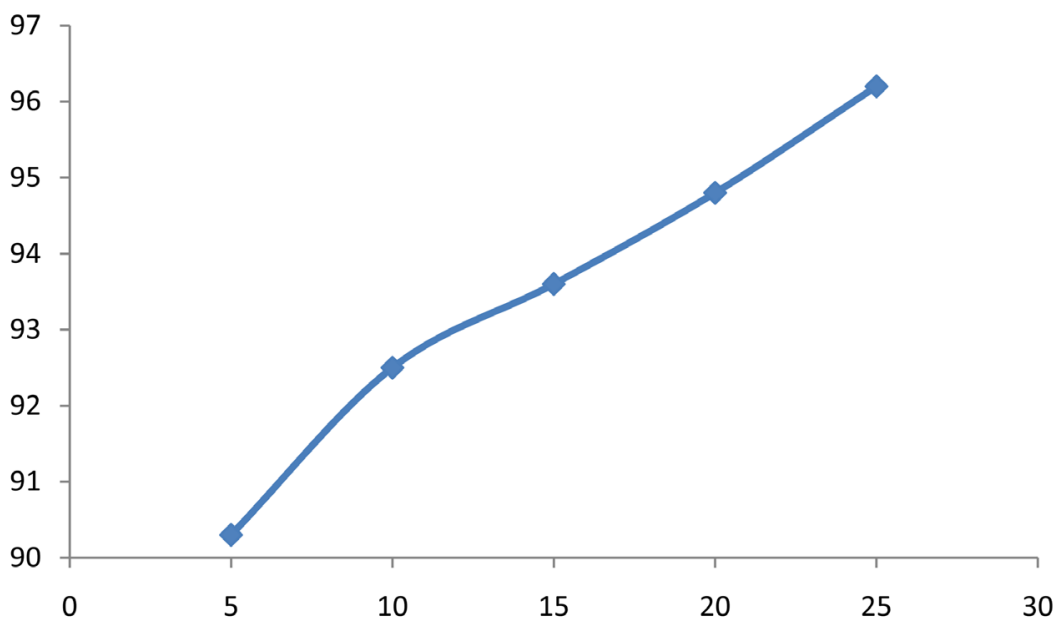

Figure 9. Effect of adding (18) ppm of $\mathrm{FeCl}_{3}$ in (100) NTU turbid water.

ternal diameter $8 \mathrm{~cm}$ ) and contained a cotton filter in the bottom of it, $\mathrm{pH}$ range $(5,7,10)$, by using $\mathrm{pH}$ adjustment $(\mathrm{HCl}, \mathrm{NaOH})$, alum and ferric chloride was used as additive. The results showed that the activated carbon had excellent results for removal turbidity, and the removal efficiency was enhanced with increasing $\mathrm{pH}$ the best results at $\mathrm{pH}(7,10)$ and also when adding alum and ferric chloride, but the effect of ferric chloride was more than alum in removing turbidity.

From the results above can be concluded that the activated carbon and cotton filter had excellent results for removal turbidity, and the removal efficiency was enhanced with increasing $\mathrm{pH}$ the best results at $\mathrm{pH}(7,10)$ and also when adding alum and ferric chloride, but the effect of ferric chloride was more than alum in removing turbidity.

For future works, there are some suggestions:

- Treat turbid water in another way and see the effect of PH in removal, like membrane, sedmintation.

- Using another additive.

\section{References}

[1] Robens Institute (1996) Fact Sheet 2.33: Turbidity Measurement. Fact Sheets on Environmental Sanitation. University of Surrey, World Health Organization.

[2] (1999) Standard Methods for the Examination of Water and Wastewater.

[3] Koohestanian, A., Hosseini, M. and Abbasian, Z. (2008) The Separation Method for Removing of Colloidal Particles 
from Raw Water. American-Eurasian Journal of Agricultural and Environmental Sciences, 4, 266-273.

[4] Droh, G., Kamagate, Seidel, L. and Jean, B. (2008) Coagulation-Flocculation Treatment of a Tropical Surface Water with Alum for Dissolved Organic Matter (DOM) Removal: Influence of Alum Dose and pH Adjustment. Journal of International Environmental Application \& Science, 3, 247-257.

[5] Nathanson, J.A. (2003) Basic Environmental Technology: Water Supply, Waste Management, and Pollution Control. Prentice Hall, Upper Saddle River.

[6] Joyce, T.M., et al. (1996) Inactivation of Fecal Bacteria in Drinking Water by Solar Heating. Applied and Environmental Microbiology, 62, 399-402.

[7] Howard Hughes Medical Institute (2001) Water Contaminant Lab. http://www.hhmi.princeton.edu/Teachers/2001/phughs/hughes/EcoWeb/downloads/waterqualitytest.htm

[8] World Health Organization (2004) Guidelines for Drinking-Water Quality. 3rd Edition, Volume 1, Recommendations, Geneva.

[9] Myre, E. and Shaw, R. (2006) The Turbidity Tube: Simple and Accurate Measurement of Turbidity in the Field. Department of Civil and Environmental Engineering Michigan Technological University.

[10] Osmonics (1991) Pure Water. Hand Book, USA.

[11] Pure Water Products, LLC.

[12] Parmar, K.A., Prajapati, S., Patell, R. and Dabhi, Y. (2011) Effective Use of Ferrous Sulfate and Alum as a Coagulant in Treatment of Dairy Industry Wastewater. ARPN Journal of Engineering and Applied Sciences, 6. 